\title{
56. DATA REPORT: NODULAR CHERT FROM SITE 817 (TOWNSVILLE TROUGH, NORTHEASTERN AUSTRALIA) ${ }^{1}$
}

\author{
Thomas C. Brachert ${ }^{2}$ and Dieter Schmidt ${ }^{2}$
}

\section{INTRODUCTION}

Nodular silifications in carbonate rocks have been documented in a variety of geological settings. Nodular cherts formed during early diagenesis (Voigt, 1979) and are common in pelagic chalks (Gruszczynski, 1986; Zijlstra, 1987) as well as in shallow-marine settings, where they are related to mixing zones (Geeslin and Chafetz, 1982), subaerial exposure surfaces (Knauth, 1979), or pseudomorphs after evaporites in peritidal dolomites (Milliken, 1979). Ghost structures after depositional textures and biota, even in dolomitic host rocks, have been described from deeper water cherts (Meyer, 1975). Carbonate "rhombohedra" in nodular chert have been described recently by Misik (1992).

Site 817 is situated on the northern side of the Townsville Trough, a $560-\mathrm{km}$-long, east-west-trending narrow basin about 70 to $150 \mathrm{~km}$ wide. The Townsville Trough separates the Queensland Plateau in the north from the Marion Plateau in the south. To the west, the site is bounded by the Great Barrier Reef; to the east, it widens into the Coral Sea Basin (Fig. 1). The trough has a smooth, flat floor that deepens gradually to the east and has a maximum depth of $2000 \mathrm{~m}$. The surface of the Queensland Plateau to the north exhibits a gentle northwest tilt having a mean depth of $1100 \mathrm{~m}$. The Marion Plateau to the south lies adjacent to the Great Barrier Reef in a water depth that ranges from $100 \mathrm{~m}$ in the west to $500 \mathrm{~m}$ in the east.

Site 817 is located on the southern margin of the Queensland Plateau, southwest of the Tegrosse/Lihou/Coringa Bank Complex (position, $18^{\circ} 94^{\prime} \mathrm{S}, 149^{\circ} 45^{\prime} \mathrm{E}$ ). Drilling at the site was performed in a water depth of $1016 \mathrm{~m}$ (Hole 817C) to $1027 \mathrm{~m}$ (Holes 817A, 817B, $817 \mathrm{D})$ and reached a depth of $670 \mathrm{~m}$ below seafloor ( $\mathrm{mbsf}$ ).

The sequence of carbonate slope sediments encountered records the middle Miocene to Quaternary history of the southern margin of the Queensland Plateau in a deeper-water setting, connecting the Queensland Plateau with the Townsville Trough (Fig. 2). The sedimentary sequence was divided into three lithostratigraphic units. Unit I is dominated by calcareous pelagic oozes and periplatform oozes with minor calciturbidites and slumps. This unit contains a thick Pleistocene and upper Pliocene section and a thinner lower Pliocene and uppermost Miocene sequence. Unit II (latest early and middle Miocene) includes reworked sediments at the top (erosion of middle Miocene), but consists mostly of calcareous chalk with bioclasts. The bioclasts increase in number downward. Unit III consists of partially dolomitized bioclastic packstones and grainstones (Subunits IIIA and IIIB, latest early to middle Miocene) that grade downward into crystalline dolomite of unknown age and environment of deposition (Subunit IIIC). Aboard the ship, the upper, calcareous part (Subunits IIIA and IIIB, 426.7-570.7 mbsf) of Unit III was tentatively interpreted to represent a base-of-slope debris apron, because of scant evidence of bioclasts (corallinaceans, foraminifers, bryozoans) derived from neritic sources. Subunit IIIC (570.7-666.8 mbsf) is distinguished by pervasive sucrosic dolomite with most of the original

'McKenzie, J.A., Davies, P.J., Palmer-Julson, A., et al., 1993. Proc. ODP, Sci. Results, 133: College Station, TX (Ocean Drilling Program).

${ }^{2}$ Institut für Geowissenschaften, Saarstr. 21, D-65 Mainz, Federal Republic of Germany, fabric destroyed. Large vugs and molds were interpreted to represent dissolved bioclasts and intraclasts.

The purpose of this report is (1) to document the mineralogical composition and texture of nodular cherts found within the dolomites of Subunits IIIB and IIIC, (2) to discuss the shipboard interpretation of the environment of deposition, and (3) to support the understanding of the process of dolomitization of the Queensland Plateau carbonates (see Swart et al., this volume).

\section{METHODS}

The petrographic description is based on 21 thin sections (one thin section per sample) of dolomite (17 thin sections) and of chert (four thin sections). The thin sections were stained with alizarin red $\mathrm{S}$. The ratio of planktonic/benthic foraminifers was counted within parallel ribbons. The width of the ribbons was chosen to be equivalent with the field observed in the microscope. Scanning electron microscope (SEM) analyses of chert were performed on broken surfaces (four

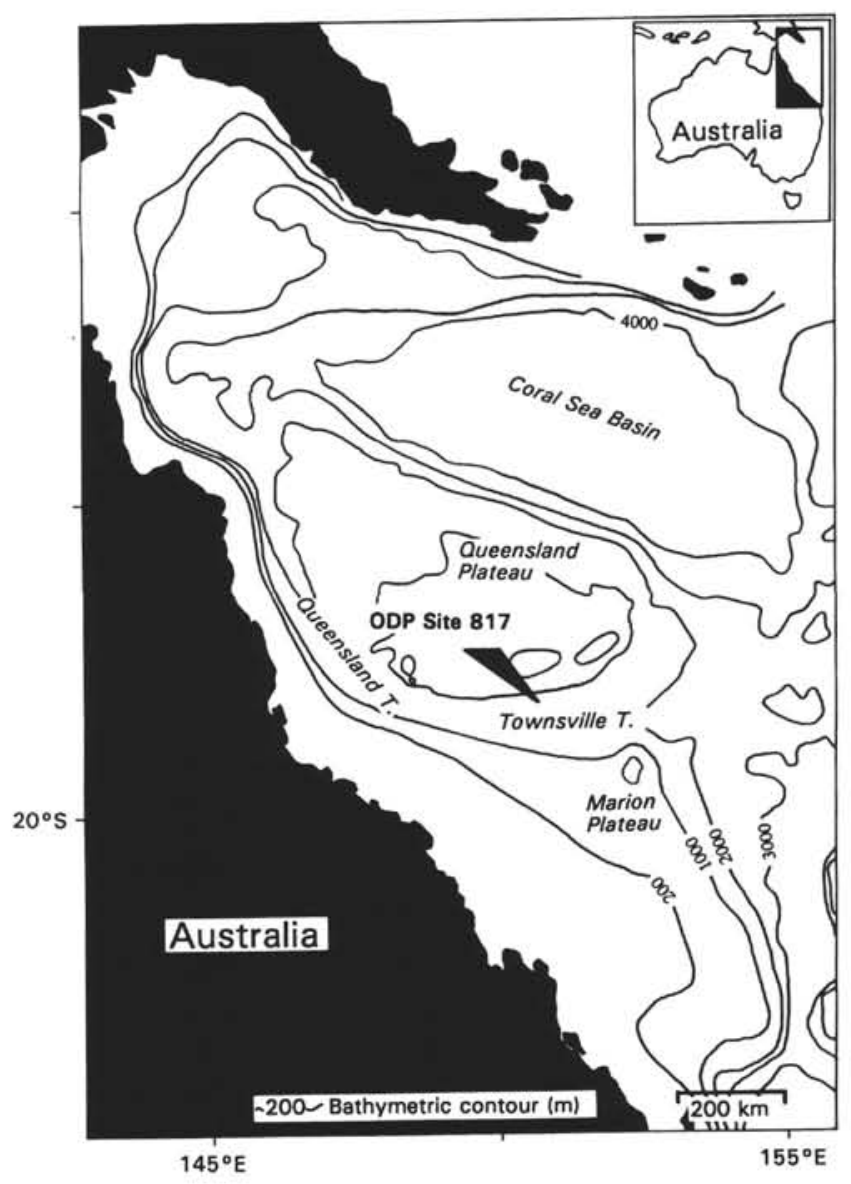

Figure 1. Locality map of Site 817. 


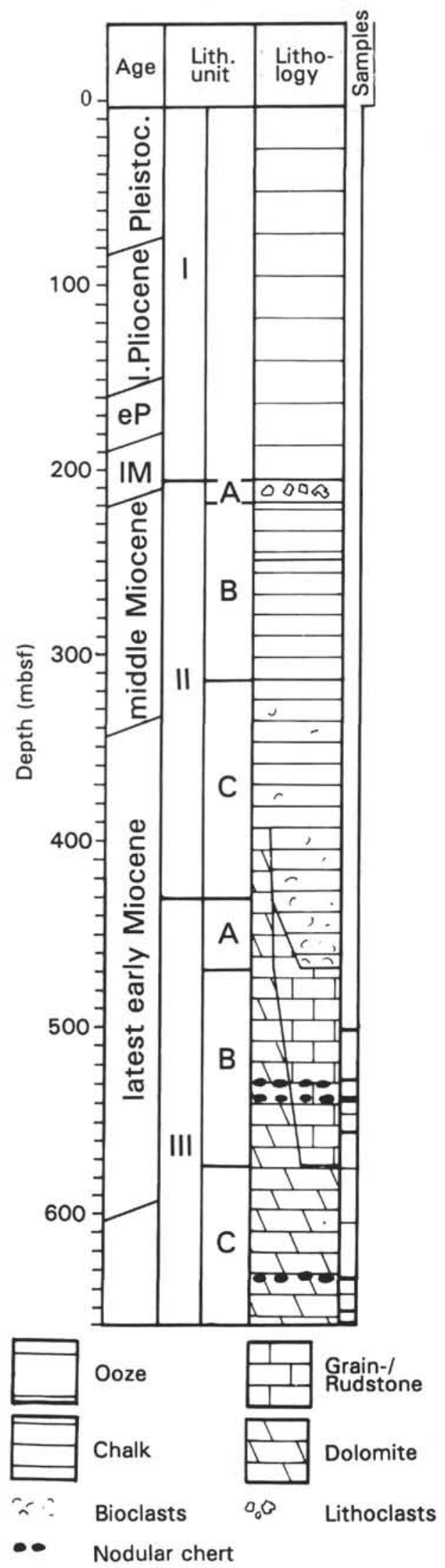

Figure 2. Lithostratigraphy of Site 817 (0-660 mbsf; redrawn from Davies, McKenzie, Palmer-Julson, et al., 1991). samples). Both the petrographic description and the SEM analyses were carried out by T.C. Brachert. The mineralogical composition using X-ray diffractometry (XRD) was determined by D. Schmidt. XRD samples of carbonates were chosen as close as possible to nodular chert. The dolomite/calcite ratio was determined after the method described by Tennant and Berger (1957); the ordering of the dolomite was calculated using the method given by Füchtbauer and Goldschmidt (1965). The carbonate content of the samples was determined using the Karbonat Bombe (Dunn, 1980). Sample locations and results are given in Figure 2 and Tables 1 through 3.

\section{DESCRIPTION OF SAMPLES}

Samples of cherts were taken from all four horizons of occurrence (Interval 133-817D-29R-1, 28-32 cm; Interval 133-817D-30R-1,

Table 1. Samples of nodular chert from Hole 817D; dolomite content of carbonate fraction.

\begin{tabular}{|c|c|c|c|}
\hline $\begin{array}{l}\text { Core, section, } \\
\text { interval }(\mathrm{cm})\end{array}$ & Carbonate $(\%)$ & Dolomite (\%) & $\begin{array}{l}\text { Dolomite, } \\
\text { Ca content }\end{array}$ \\
\hline \multicolumn{4}{|l|}{ 133-817D- } \\
\hline $29 \mathrm{R}-1,30-33$ & 9.5 & 0.4 & $\mathrm{Ca}_{51} \mathrm{Mg}_{49}$ \\
\hline $30 \mathrm{R}-1,0-4$ & 11 & - & - \\
\hline $30 \mathrm{R}-1,90-94$ & 9.5 & 7.5 & $\mathrm{Ca}_{56} \mathrm{Mg}_{44}$ \\
\hline $40 \mathrm{R}-1,9-12$ & \multicolumn{2}{|c|}{ No sample available } & \\
\hline
\end{tabular}

Note: $-=$ no dolomite present.

Table 2. List of carbonate samples used for petrographic study, Hole 817D.

\begin{tabular}{|c|c|}
\hline $\begin{array}{l}\text { Core, section, } \\
\text { interval }(\mathrm{cm})\end{array}$ & Lithology \\
\hline \multicolumn{2}{|l|}{ 133-817D- } \\
\hline $26 \mathrm{R}-1,129-132$ & Foraminifer packstone \\
\hline $26 \mathrm{R}-2,1-5$ & As above \\
\hline $29 \mathrm{R}-1,26-29$ & $\begin{array}{l}\text { Finely grained crystalline carbonate with relicts of planktonic } \\
\text { foraminifers, Chondrites }\end{array}$ \\
\hline $30 \mathrm{R}-1,5-9$ & Foraminifer packstone \\
\hline $30 \mathrm{R}-1,45-49$ & Foraminifer packstone, Chondrites \\
\hline $30 \mathrm{R}-1,75-78$ & As above, euhedral dolomite \\
\hline $31 \mathrm{R}-1,78-82$ & Foraminifer packstone, Chondrites \\
\hline $32 \mathrm{R}-1,19-23$ & Foraminifer-bioclast grain-packstone \\
\hline $32 \mathrm{R}-1,58-61$ & As above \\
\hline $34 \mathrm{R}-\mathrm{CC}, 0-3$ & Sucrosic dolomite \\
\hline $37 \mathrm{R}-1,20-24$ & $\begin{array}{l}\text { Finely grained crystalline carbonate with relics of planktonic } \\
\text { foraminifers }\end{array}$ \\
\hline $40 \mathrm{R}-1,4-9$ & Microbioclastic wackestone, abundant euhedral dolomite rhombs \\
\hline $41 R-1,24-30$ & As above \\
\hline $42 \mathrm{R}-1,1-4$ & $\begin{array}{l}\text { Zonar, sucrosic dolomite, irregularly truncated by hardground, } \\
\text { very porous; above: foraminifer packstone }\end{array}$ \\
\hline $42 \mathrm{R}-1,4-10$ & Microbioclastic wackestone, abundant euhedral dolomite rhombs \\
\hline $42 \mathrm{R}-1,43-45$ & As above \\
\hline $43 \mathrm{R}-\mathrm{CC}, 0-3$ & Sucrosic dolomite, very porous; few echinoderms and red algae \\
\hline
\end{tabular}

Table 3. Dolomite content (\%) of carbonate samples from Hole 817D.

\begin{tabular}{lccc}
\hline $\begin{array}{l}\text { Core, section, } \\
\text { interval }(\mathrm{cm})\end{array}$ & Carbonate (\%) & Dolomite (\%) & $\begin{array}{c}\text { Dolomite, } \\
\text { Ca content }\end{array}$ \\
\hline 133-817D- & & & \\
$29 \mathrm{R}-1,26-29$ & 83 & - & - \\
$30 \mathrm{R}-1,5-9$ & 91 & 5 & $\mathrm{Ca}_{54} \mathrm{Mg}_{46}$ \\
30R-1, 9-12 & 89 & 45 & $\mathrm{Ca}_{51} \mathrm{Mg}_{49}$ \\
$32 \mathrm{R}-1,19-23$ & 99 & 7 & $\mathrm{Ca}_{54} \mathrm{Mg}_{46}$ \\
$32 \mathrm{R}-1,58-61$ & 98 & 10 & $\mathrm{Ca}_{51} \mathrm{Mg}_{49}$ \\
40R-1, 4-9 & 88 & 75 & $\mathrm{Ca}_{51} \mathrm{Mg}_{49}$ \\
\hline
\end{tabular}

Note: $-=$ no dolomite present. 


\section{A}

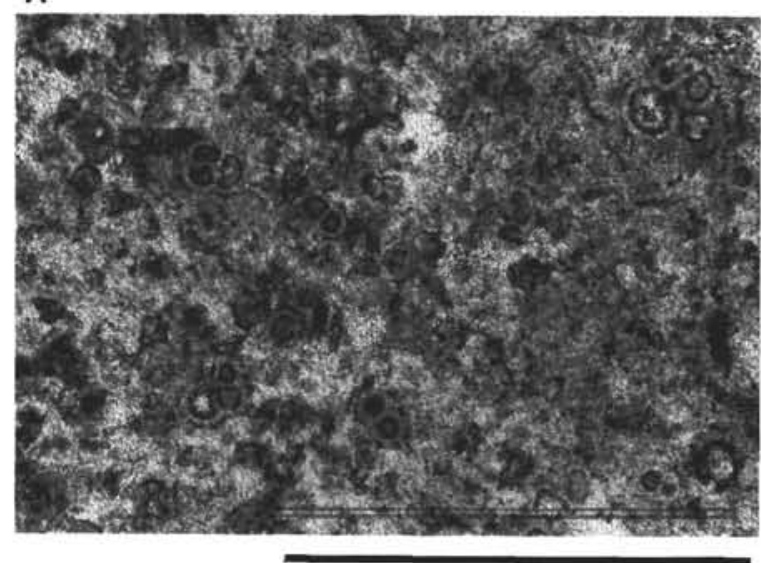

B

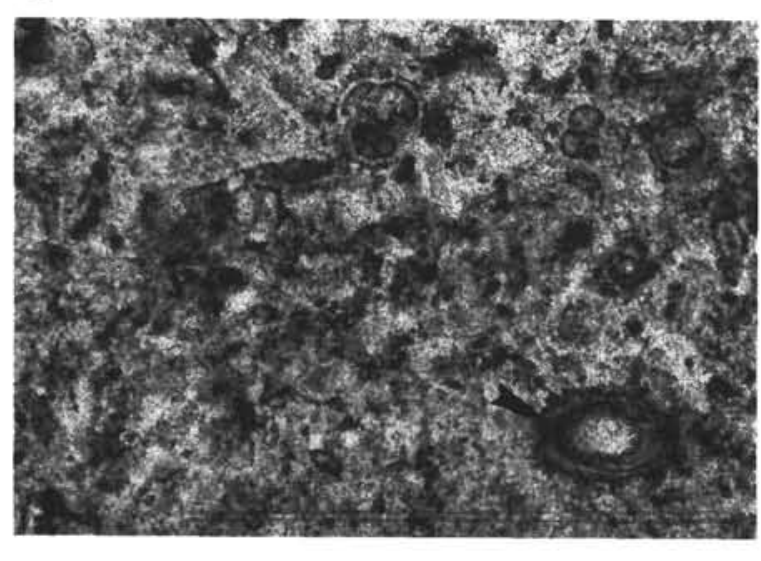

Figure 3. Thin-section photomicrographs of nodular chert from Site 817 (Sample 133-817D-29R-1, 30-33 cm). A. Ghost structures after planktonic foraminifers. B. Ghost structures after planktonic foraminifers and serpulid (arrow). Although marginally corroded, the tube and its intraparticle cement have not been silicified. Scale bars $=0.5 \mathrm{~mm}$.

1-5 cm, and 87-93 cm; Interval 133-817D-40R-1, Pieces 3 and 4; Fig. 2). To document the variations of microfacies preserved in chert and embedding sediment, samples from the surrounding rock were taken as close as possible to the chert samples.

\section{Chert}

The chert nodules are potato-shaped bodies several centimeters in diameter. In polished slabs, the color is commonly dark gray and is darkest along the margins of the concretions, which are exactly defined. Irregular patches of light-gray colors occur within the center; these are more or less concentrically surrounded by well-defined lighter and darker bands.

The degree of silification is variable. Light-gray zones of the cherts are rich in porosity and in calcareous inclusions. Except for some mollusk fragments and probable serpulid tubes with cement linings preserved (Fig. 3B), the carbonate fraction consists of anonymous particles (maximum diameter, $100 \mu \mathrm{m}$ ).

In thin sections, the cherts have a clotted appearance because of spots of darker silifications (100 to $1000 \mathrm{~mm}$ ), which may be relict of a micritic matrix or because of an elevated content of pyrite (Fig. 3). In places, the spots are densely spaced to form dark patches of several millimeters in distinct structures of former burrows. Groups of smaller, irregular brown spots 200 to $400 \mathrm{~mm}$ wide and up to $5 \mathrm{~mm}$ long occur; these may be assigned to the trace fossil Chondrites. Ghost structures of calcareous microfossils, such as planktonic and benthic foraminifers (Fig. 3), are common. The planktonic/benthic ratio is 13:1 in the sample from Interval 133-817D-20R-1, 30-33 cm, 6:1 in the sample from Interval 133-817D-30R-1, 0-4 cm, and 11:1 in the sample from Interval 133-817D-40R-1, 9-12 cm. In Sample 133-817D-30R-1, 90-94 cm, the ratio of planktonic and benthic foraminifers was not counted because of too few preserved ghost structures. The tests of the foraminifers always have a fine, dark lining at the inner margin of their chamber walls that is absent on their outer surfaces. The interior of larger individuals shows ghost structures of dark geopetal infillings, which may represent former micrite. In contrast to serpulid tubes and mollusk valves, foraminifers having their original calcitic tests preserved do not occur. Silicified ostracodes occur subordinately. Under crossed nicols, the ghost structures after foraminifers and other microfossils are invisible. Incomplete ghosts of microfossils down to unidentifiable particles may represent bioclasts or may be due to incomplete fossil record. These various objects reveal wackestone to packstone textures (Fig. 3). In one nodule (133-817D-30R-1, 90-94 cm), tiny rhombs of 20 to $30 \mathrm{~mm}$ were found scattered throughout the thin section (Fig. 4). These rhombs do not stain with Alizarin red S. They are interpreted to represent dolomite. Under the SEM, a fine-grained mosaic of interlocking quartz crystals was found. The maximum grain size of the quartz crystals is $10 \mu \mathrm{m}$.

According to X-ray diffractometry, the nodules consist of quartz with lesser amounts of carbonate $(9.5 \%-11 \%)$. If present, dolomite represents $75 \%$ of the carbonate fraction. The dolomite is poorly ordered with $51-56 \mathrm{~mol} \%$ of calcium. Clay minerals are extremely minor. Opal-CT was not found in diffractograms.

\section{Carbonates}

Samples of carbonate material exhibit various degrees of dolomitization (Table 3). Although not constant, increasing dolomitization downhole in the analyzed section is the general trend. Undolomitized carbonates are represented by planktonic foraminifer wackestone or packstone, or less commonly by foraminifer-bioclast grain/packstone. The first is interpreted to represent a hemipelagic foraminifer ooze, the latter to represent an allochthonous carbonate derived from shallow water. A brief description of the lithologies encountered is given in Table 2.

The dolomite forms a crystalline carbonate that is dark yellow to brown and consists of mosaics of interlocking crystals. Individual rhombs, which exhibit distinct zonation, enclose a dark micropelletoid nucleus. Presumably, depending on the degree of dolomitization, the intercrystalline space is micritic or intercrystalline porosity in sucrosic dolomite. The maximum intercrystalline porosity (as estimated from thin sections) is $5 \%$ to $10 \%$. In addition, vugs and molds after bioclasts are seen. Moldic pores are aligned by clear crystals growing toward the centers of the pores. The only grains preserved are rare echinoderm ossicles and fragments of corallinacean algae. The outline of the corallines is ragged because of marginal corrosion from growth of euhedral dolomite rhombs.

\section{DISCUSSION AND CONCLUSIONS}

In cherts, the dense packing of ghost structures after foraminifers and their high planktonic/benthic ratio $(>6: 1)$ indicate a deeper marine, hemipelagic/pelagic setting. This suggests a similar environment of deposition for the precursor of most of the dolomitic samples as well. Because of the presence of few relics of shallow marine particles, as well as indications of graded bedding within some carbonate samples, such levels may originally represent calcareous turbidites (Davies, McKenzie, Palmer-Julson, et al., 1991).

Interestingly, planktonic foraminifers, which are the dominant biotic constituents documented in cherts, are found only very subordinately in dolomite samples. On the other hand, primary magnesian 
calcitic biota (echinoderms, corallinaceans) are only occasionally recorded within chert nodules where they are not silicified. Because of poor control on the position of the samples taken (partial recovery), it is not clear whether this difference in the biotic composition reflects a depositional pattern or is biased by diagenetic processes.

The first step of dolomitization (tiny isolated rhombs) predates the chert, whereas the main phase of dolomitization (sucrosic dolomite) obviously postdates silification of the original carbonate. Thus, dolomitization seems to have started during early diagenesis and continued for a longer period of time.

\section{ACKNOWLEDGMENTS}

Thanks are due to the Deutsche Forschungsgemeinschaft, Bonn, for supporting the present study. A constructive review was made by J.B. Keene (Sydney).

\section{REFERENCES}

Davies, P.J., McKenzie, J.A., Palmer-Julson, A., et al., 1991. Proc, ODP, Init. Repts., 133: College Station, TX (Ocean Drilling Program).

Dunn, D.A., 1980. Revised techniques for quantitative calcium carbonate analysis using the "Karbonat-Bombe," and comparisons to other quantitative carbonate analysis methods. J. Sediment. Petrol., 50:631-637.

Füchtbauer, H., and Goldschmidt, M., 1965. Beziehungen zwischen Calciumgehalt und Bildungsbedingungen der Dolomite. Geol. Rundsch., $55: 29-40$.

Geeslin, J.H., and Chafetz, H.S., 1982. Ordovician ribbon cherts: an example of silification prior to carbonate lithification. J. Sediment. Petrol., 52:1283-1293.
Gruszczynski, M., 1986. Hardgrounds and ecological succession in the light of early diagenesis (Jurassic, Holy Cross Mts., Poland). Acta Palaeontol. Polon., 31:163-277.

Knauth, L.P., 1979. A model for the origin of chert in limestone. Geology, 7:274-277.

Meyer, R.K.F., 1975. Mikrofazielle Untersuchungen in Schwamm-Biohermen und-Biostromen des Malm Epsilon und obersten Malm Delta der Frankenalb. Geol. Bl. Nordost-Bayern, 1975:149-177.

Milliken, K.L., 1979. The silicified evaporite syndrome-two aspects of silification history of former evaporite nodules from Kentucky and northern Tennessee. J. Sediment. Petrol., 49:245-256.

Misik, M., 1992. Carbonate rhombohedra and other phenomena in nodular cherts (Mesozoic, West Carpathians). 9th Meeting of Carbonate Sedimentology, Liverpool Univ.

Tennant, C.B., and Berger, R.W., 1957. X-ray determination of dolomite-calcite ratio of a carbonate rock. Am. Mineral., 42:23-29.

Voigt, E., 1979. Wann haben sich die Feuersteine gebildet? Nachr. Akad. Wiss. Goettingen, Math.-Phys. Kl., 2B: Biol.-Physiol.-Chem. Abt., 1979/6:75-129.

Zijlstra, H.J.P., 1987. Early diagenetic silica precipitation, in relation to redox boundaries and bacterial metabolism, in Late Cretaceous chalk of the Maastrichtian type locality. Geol. Minjbouw, 66:343-355.

Abbreviations for names of organizations and publication titles in ODP reference lists
follow the style given in Chemical Abstracts Service Source Index (published by American Chemical Society).

Date of initial receipt: 7 April 1992

Date of acceptance: 10 December 1992

Ms 133SR-274

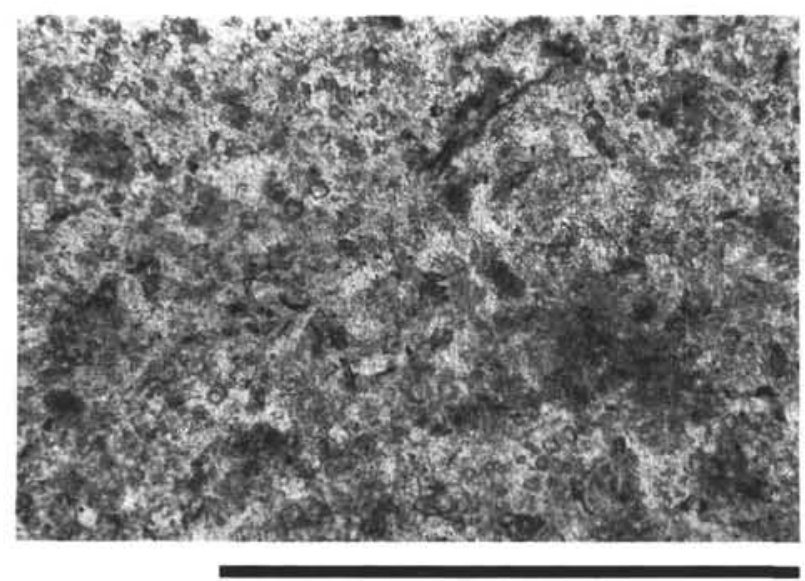

Figure 4. Thin-section micrograph of nodular chert (Sample 133-817D-30R-1, $90-94 \mathrm{~cm}$ ). Tiny dolomite rhombs are scattered throughout the nodules. Scale bar $=0.5 \mathrm{~mm}$. 